\title{
ADMINISTRATIVE POWERS IN TERMINATING ADMINISTRATIVE SINGLE-CASE DECISIONS IN ROMANIA
}

The whole activity of the public administrative bodies is governed by the principle of legality. Single-case decisions are an important part of this activity. The procedure for issuing administrative decisions has to be precise and ensure the predictability of law. Nevertheless, errors may occur and situations related to an already issued administrative single-case decisions may change. The administrative bodies have to be able to straighten things by ending the effects of illegal single-case decisions or of decisions that are no longer in accordance with the law or endanger the public interest. This power must not be used in a way that violates human rights. The paper analyses the rules regarding the power of administration to terminate the effects of single-case decisions in the Romanian legal system, respectively the rules for annulment and withdrawal of such decisions. Both annulment and withdrawal of single-case decision making have different effects in accordance with the reasons for their application. As Romania has recently adopted the Administrative Code, but does not yet have yet an administrative procedure law, the analysis aims to determine how the traditional rules cope with the protection of human rights. A comparison with the legal rules provided by the administrative procedure laws in Balkan countries is presented.

Keywords: administrative decisions, nullity, withdrawal, human rights

\section{INTRODUCTION}

Administrative bodies carry out the executive function of the state. Their activities aim to implement the laws adopted by the Parliament and the Government Ordonnances issued by the Government, when empowered by the Parliament, and to provide public services. Organising the implementation of laws and implementing laws are processes carried out through legal decisions and activities with or without legal effect. Most of the legal decisions issued or adopted by the administrative authorities in these processes are

* PhD, Associated Professor, „Dimitrie Cantemir” Christian University, Faculty of Law Cluj-Napoca, ORCID number 0000-0003-0001-9134. Email: mihaelafodor@yahoo.co.uk. 
single-case (individual) administrative decisions. The Administrative Code of Romania, recently approved by Government Emergency Ordinance no. 57/2019 ${ }^{312}$, mentions first, among the principles listed in Art. 6, the principle of legality. Based on this principle, the administrative authorities are allowed to terminate the effects of the single-case (individual) decisions, if they find out that they were illegally issued. In absence of a law regarding administrative procedure, Romanian legal theory has developed a series of principles and rules that guide the administration in using the power of terminating the effects of singlecase (individual) administrative decisions. These rules are necessary for balancing the need for legality and the principle of legal stability and the respect of human rights, and were hence developed along with the increase in force of the last two principles aforementioned. Our previous work (Fodor, 2016) has focused on a comparison of Romanian rules in the matter with the legislation of western EU countries (Germany, Italy, The Netherlands). The present paper is looking for a comparison with the legislation of the Balkan area, which we think that it is beneficial for shaping solutions.

In the case of normative administrative decisions, the usual way of terminating their effects is abrogation, which terminates the effects of the legal acts only for the future, so no particular problems can be encountered in this area.

Our research aimed to find how the principles and rules regarding the termination of the effects of single-case (individual) administrative decisions are shaped in recent years in order to ensure a better protection of human rights and to highlight valuable codification ideas contained in the legislation of some Balkan countries. We have sought to find how the administrative procedure laws of different states regulate the annulment and revocation in terms of who has the competence to annul or revoke a decision, whether the annulment or the revocation acts have ex nunc or ex tunc effects, whether there are time limits for annulling or revoking single-case administrative decisions or whether there are special conditions that enable an administrative body to do so.

\section{POSSIBLE SITUATIONS FOR TERMINATION OF THE EFFECTS OF A SINGLE- CASE (INDIVIDUAL) ADMINISTRATIVE DECISION BY AN ADMINISTRATIVE AUTHORITY IN THE ROMANIAN LAW}

The termination of the effects of a single-case (individual) administrative decision may be a legal sanction in case the validity conditions for such a legal act were not met at the moment it has been issued/adopted. In order to preserve legality, the competence to terminate the effects of such an administrative decision is given to the issuing authority, as a result of an internal administrative control (Iorgovan, 2001, p. 455), to the hierarchic superior authority, as a result of a hierarchic administrative control (Fodor, 2017, pp. 233-234), or to a specialised administrative authority, as a result of a specialised control (Petrescu, 1997, p. 317). Internal, hierarchic or specialised controls may be conducted as a result of a request made by an interested party or ex officio. The competent administrative authorities will issue a new administrative decision for terminating the illegal previous one.

${ }^{312}$ Published in the Official Gazette of Romania, no: 555/2019. 
The requirements for the validity of an administrative decision have been set by the doctrine and case-law, as Romania has not yet adopted a law governing administrative procedure. Generally it is accepted that, in order to be valid, the administrative decision has to fulfil the following requirements: (i) to be issued by the competent authority within the limits of its competence; (ii) to be issued in the form and following the procedure established by law; (iii) to be in concordance with the Constitution, the laws and other legal norms in force; (iv) to meet the public interest (to meet the condition of desirability, the issuing of the administrative decision to be recommendable, advisable, which is known in French literature as l'opportunité de l'acte administratif unilatéral) (Ionescu, 1970, pp. 250-251; Iovănaş, 1997, p. 35; Petrescu, 2004, p. 297). The third condition is shaped by the constitutional provisions referring to the international conventions Romania is a party to. According to Art. 20 of the Romanian Constitution "Constitutional provisions concerning the citizens' rights and liberties shall be interpreted and enforced in conformity with the Universal Declaration of Human Rights, with the covenants and other treaties Romania is a party to" and "Where any inconsistencies exist between the covenants and treaties on the fundamental human rights Romania is a party to, and the national laws, the international regulations shall take precedence, unless the Constitution or national laws comprise more favourable provisions". Given the fact the Romania is an EU member state, Art. 148 para. 2 of the Constitution stipulates that "the provisions of the constituent treaties of the European Union, as well as the other mandatory community regulations shall take precedence over the opposite provisions of the national laws, in compliance with the provisions of the accession act". Thus, the Romanian Constitution creates a "constitutional block" including the Constitution itself and the international legal acts that Art. 20 and art. 148 refer to, all with the same legal force, at the top of the hierarchy of legal norms (Popescu, 2000, pp. 262-269). This block also contains the case-law of the international courts competent to supervise the way states respect the international conventions they have adhered to, respectively the European Court of Human Rights and the Court of Justice of the European Union.

Not all the omissions in meeting the requirements or conditions for the validity of the administrative decisions attract the same rules regarding the termination of their effects. The first three conditions for validity are known as conditions for the legality of the administrative decision. These conditions have to be met when the administrative decision is issued. If one of the three requirements was not respected, the effects of the administrative decision may be terminated both by an administrative authority and by the competent courts. The fourth condition, meeting the public interest (the desirability, or the advisability of the administrative decision) can be observed at the time the single-case (individual) administrative decision is issued, or at a later date, if the premises linked to the objective of the administrative decision have changed. Only an administrative authority has the competence to terminate the effect of an administrative decision on grounds of desirability or advisability, either because the public interest in accordance with the law was not met at the moment the administrative decision was issued, or because circumstances have changed and it is no longer serving the purpose of the law. The courts have no competence in assessing whether this fourth condition was or is still met. The effect of an 
administrative decision for terminating a previous one differs in accordance with the reason for termination. If the reason is noncompliance with a legality condition of validity, the effects of the administrative decision for termination of a previous single-case (individual) decision will be extunc, whenever this is possible in fact. If the reason is noncompliance with the desirability condition (l'opportunité), the effects of the administrative decision for termination of a previous single-case (individual) decision will be ex nunc.

\section{METHODS FOR TERMINATION OF THE EFFECTS OF A SINGLE-CASE (INDIVIDUAL) ADMINISTRATIVE DECISION BY AN ADMINISTRATIVE AUTHORITY IN THE ROMANIAN LAW}

Administrative authorities can terminate the effects of single-case (individual) administrative decisions either by annulling or by revoking them.

The distinction between annulment and revocation is discussed at doctrinal level. Some older authors (Iovănaş, 1997, p. 253) consider that revocation of a single-case (individual) administrative decision may be decided by the administrative authorities (the issuing authority or the hierarchically superior authority) in case of a breach of any validity conditions (legality conditions or advisability condition), while the annulment may be decided by a specialised administrative authority only for breaching one of the three legality conditions for the validity of administrative decisions. This theory allows the issuing or hierarchic authorities to annul or revoke a single-case (individual) administrative decision for a breach of a legality condition of validity, without making any difference between the two possible methods. Other, more recent authors (Petrescu, 2004, pp. 323-326), consider that both revocation and annulment may be decided for breaching any validity condition of the administrative decision (legality or advisability), revocation being decided by the issuing or hierarchically superior authority. A third opinion (Santai, 2011, pp. 175-185) considers that the issuing authorities and hierarchically superior authorities may revoke a single-case (individual) decision as being illegal, unadvisable or as a sanction for certain illegal behaviours of the beneficiary, while specialised competent administrative authorities may annul such decisions if there is a breach of the legality condition of validity. In all the cases, if the single-case (individual) decisions are revoked by the issuing authority, the operation is named withdrawal.

From the dispositions of the Administrative Code, we can conclude that revocation of a single-case (individual) administrative decision can be decided by the issuing administrative authority if the decision is illegal or unadvisable (Art. 26 para. 2 shows that the Government may ask the subordinate administrative authorities to revoke decisions that are illegal or inadvisable) and by the hierarchic superior authority if the decision is illegal (Art. 245 para. 8 shows that the Government may revoke an illegal decision of a prefect). The wording of the Administrative Code also hints to the fact that the control of the advisability of an administrative decision is an exclusive prerogative of the issuing authority, the hierarchicially superior authority or any other authority being competent to verify only the legality of an administrative decision issued by another authority. This would make sense, as assessing the advisability of an administrative decision should be in connection with the competence for issuing it. 


\subsection{Annulment of single-case (individual) administrative decisions}

In respect to the annulment of the administrative decisions in general, and hence of the single-case (individual) decisions as well, one problem discussed in the doctrine is the legal regime of the nullity in the Romanian administrative law.

Major authors in the field of administrative law define nullity as a manifestation of will aiming to directly terminate the act and eradicate its juridical effects (Iorgovan, 2001, pp. 69-70; Petrescu, 2004, p. 319). The first thing to be observed about this definition is that it does not match the definition for nullity in civil law, as it does not mention the reason for annulment of an administrative act, the extension of nullity's effects and is not referred to as a sanction. In civil law, nullity is defined as a sanction consisting in undoing, with retroactive action, of the effects of a legal act when there is a breach of the legal conditions in issuing or concluding the act.

Nullity is always discussed as one of the ways for ending the effects of an administrative act. Although the definition does not show the reasons for which an administrative act may be annulled, comments on nullity indicate that the infringement of the conditions for issuing the act may result in annulment. Thus, it has been argued that the type of nullity that may affect an administrative act depends on the seriousness of the vice breaching the legality of the act (Iorgovan, 2001, p. 70) or the validity conditions imposed for the act (Anghene, 1958, p. 174). Such comments lead to a conclusion that, in administrative law, like in civil law, the reason of nullity is linked with the moment of issuing the act, nullity being the sanction for noncompliance with the validity conditions. Express recognition of this conclusion is to be found in the statement that no matter which authority is annulling the administrative act, the reason may lay only in causes prior or concomitant with the issuing moment ${ }^{313}$ (Iorgovan, 2001, p. 78). Recent amendments in the Law no. 554/2004 $4^{314}$ regarding the procedure in administrative courts suggest the same. According to Art. 8 para. 2 of this law, the administrative courts are competent to solve cases regarding: public procurement procedure conducted prior to concluding a contract, matters connected with the concluding of the contract and matters concerning the nullity of the contract. All litigious matters regarding the execution or terminating the public procurement contract (except for of nullity) are in the competence of civil courts. This supports the idea that nullity is a sanction for breaching the legal requirements during the procedure prior to the conclusion of the public procurement contract and at the moment of concluding such a contract. Any subsequent event does not constitute grounds for annulling the public procurement contract.

Other comments, however, suggest that the reason for annulling an administrative act may be subsequent to the moment of issuing the act. It has been stated that when the individual or normative administrative act would contravene, expressly or implicitly, the

\footnotetext{
${ }^{313}$ The reference to a moment prior to issuing the act is the consideration of the procedural formalities that might be required in order to issue an administrative act, such as an advice note or an expertise. Compliance with the requirements concerning such prior formalities is also considered a condition of validity of the administrative act, a component of the condition of complying with the issuing procedure.

${ }^{314}$ Published in The Official Gazette of Romania no. 1154/2004.
} 
situation created by abrogation of a law or annulment of a normative administrative act that was the basis for issuing the individual administrative act, the former act becomes illegal and thus it is null (Ionescu, 1970, p. 282). The Project for a Romanian Code for Administrative Procedure (Anon., 2004) also mentions in article 139 paragraph (5), that the grounds for annulment of the administrative act may be prior, concomitant or subsequent to the moment of issuing/adopting the act. From the text of paragraph 6 of the same article, two subsequent reasons for annulling the act are to be determined: 1) the right/material advantage conferred by the act is used for a different purpose than the one mentioned in the act and 2) the act is issued under a condition and the beneficiary of the act fails to meet the condition, or fails to meet the condition in the provided time interval, due to own fault. However, in such situations, the act is subjected to a cancellation condition (subsequent condition) and if the condition is met (the advantage is not used for its purpose, the term is exceeded) the sanction is the resolution of the act and not its nullity.

It is true that an administrative act may become illegal for reasons subsequent to the moment of entering into force, such as the reasons described by the Project for the Romanian Code for Administrative Procedure or because the advisability condition is no longer met for reasons subsequent to the moment of entering into force. In this case the act may be simply terminated by issuing/adopting another administrative act with this purpose, without using the term "annulment". This interpretation is also consistent with the case-law of the High Court of Cassation and Justice (HCCJ), which stated that the court, acting on a request to annul the administrative decision, has the power only to examine the conformity of the decision with legal acts of a higher rank which constituted the basis of issuing the contested act, with subsequent legal events having no effects on the contested act, but only on the moment to which it stays in force (HCCJ, 2008). The ruling of the HCCJ is consistent with French law that considers only the abrogation and revocation as reasons for the ending of the effects of the administrative acts for reasons subsequent to the issuing moment; annulment is mentioned only in respect of the power of hierarchically superior authorities or administrative courts, if the conditions of validity for the administrative act have been breached (Foillard, 2009, pp. 214-221). Nullity is perceived as a sanction for breaching validity conditions (Rivero \& Waline, 2004, pp. 362-363).

A difference in respect to civil law is the one regarding the extension of effects of nullity.. Although it is generally recognised that the effect of the nullity of an administrative act is retroactive (Iorgovan, 2001, p. 78; Iovănaş, 1997, p. 257), the possibility of only for the future effect of the nullity is mentioned. It is true that only legal effects of the annulled act may be undone, not the facts that occurred during the existence of the administrative act (Drăganu, 1959, p. 247) (for instance, if the act of nomination of a public servant is annulled, the person may retain the payment for the activity he performed and the duration of the work will be taken into account for determining the pension rights) (Ghimpu, 1985, p. 123); but authors in old literature (Ionescu, 1970, p. 283; Drăganu, 1959, p. 284), sustained by recent authors (Iorgovan, 2001, p. 79) (Petrescu, 2004, p. 324) consider that if the reason for the nullity lies in breaching the validity condition of the advisability of the act, the effects of the nullity will not be retroactive, but will only apply in the future. In our opinion, the sense of the notion of nullity has to be maintained constant throughout the legal system. 
Therefore, the reason for annulling an administrative decision may be only a breach of a legality condition for issuing/adopting the act and the effect of the annulling decision should be retroactive, in respect of the principle quod nullum est nullum producit effectum.

As to the time limit, it is notable that, although there is a tight time limit for contesting a single-case (individual) administrative decision before the courts (30 days to request the withdrawal of the decision from the issuing or hierarchically superior administrative authority from the date the decision was notified to the beneficiary or from the date a third party had knowledge of the existence and content of the administrative decision, and afterwards 6 months to address the court from the date the issuing/hierarchic superior authority has rejected the withdrawal request), there is no limit for an administrative authority to annul a single-case (individual) administrative decision.

\subsection{Revocation of single-case (individual) administrative decisions}

Due to the considerable decision-makingpower of the administration, the possibility for it tof revoke its own decisions is generally recognized. The revoking of a single-case decision is understood as the possibility of the issuing authority to terminate it for the future or with retroactive effects. Usually revocation may occur with retroactive effect, because the single-case decision breaches the law or, with prospective effect, because the circumstances considered at the issuing moment have altered or views have changed in such a way that they are opposing to the continuance of the effects of the decision.

Exceptions from the possibility of revocation are considered the jurisdictional administrative decisions, the administrative single-case (individual) decisions that were used to obtain civil contracts (exception referred to in Art. 1 para. (6) of Law 554/2004), the administrative decisions considered as non-revocable by the law and the administrative decisions granting certain rights, which were fully executed. These exceptions do not exclude the possibility of the court to annul the decision, within the time-limit established by the law. The revocation of an unlawful single-case decision obtained by fraud is always possible (Petrescu, 2014, pp. 327-331), even if one of the situations that generally exempts the possibility of revocation is present. The revocation of an unlawful single-case (individual) administrative decision usually has a retroactive effect, while the revocation of a lawful decision will only have effect for the future. A particular situation refers to authorizations. The ones legally issued by the administrative authorities in the exercise of their discretionary power, regarding continuous activities (licenses) may be revoked. The revocation does not give the right to financial compensation, as it is presumed that the beneficiary was aware of the possibility of revocation from the very beginning; compensation may only be granted if there is a special provision of the law, if the withdrawal decision is unlawful or unreasonable (an abuse of power) (Iorgovan, 2002, pp. 90-91).

No time limit is set for the revocation of an unlawful decision.

The Project of the Code for Administrative procedure mentions that revocation (revocarea) dissolves the illegal administrative disposition with retroactive and prospective effect, for reasons that proceed, are concomitant or subsequent with the issuing/adopting the decision. The decision may be revoked only within the time limit for legal challenge. A 
favourable decision that grants continuous advantages may be revoked only if the advantages are used for another purpose than the one they were granted for, or if the beneficiary fails to comply with a condition related to the decision or fails to comply with it within the set time limit. Jurisdictional decisions cannot be revoked, nor can other decisions according to law (Art. 141). In our opinion, the provisions of the Project in this matter are a step back from the rules applied at this moment and even further from the European vision.

A set of rules of unified Administrative Procedure for the European Union has been proposed by the European Law Institute, one of the aims of the project being the creation of model administrative procedure rules for the EU countries. The ReNEUAL Model Rules (Hofmann, et al., 2014) provide the possibility of revocation (the document uses the term withdrawal, but with the meaning of revocation) for both lawful and unlawful singlecase decisions that adversely affect a party. The public authority may revoke an unlawful administrative decision which adversely affects a party, ex officio or following a request of that party, with retroactive effect, outside the time-limits for legal challenge (Section III-35). The same rules apply for the revocation of a lawful administrative decision which adversely affects a party, but with prospective effect. In both cases the public authority shall take into account the effect of the revocation on other parties and on third parties.

When a decision to revoke an unlawful decision which is beneficial to a party is considered, the public authority shall take into account the extent to which a party has a legitimate expectation that the decision was lawful and the extent to which the party has relied on it. In respect to these factors, the public authority will decide whether it will exercise the power to revoke the decision, the retroactive or prospective effect of the revocation. The revocation may be exercised ex officio or following a request of that party, outside the time-limits for legal challenge (Section III-36).

The public authority may revoke a lawful decision that is beneficial to a party, ex officio, or following a request of another party. The power of revocation in such a case may be exercised outside the time-limits for legal challenge only if it is permitted by specific law, if the party has not complied with an obligation specified in the decision or has not done so within the time-limit set for compliance or in order to prevent serious harm. In the last case, upon application, the public authority shall make good the disadvantage to the party affected, to the extent that the reliance on the continued existence of the decision merits protection. The effect of the revocation on other parties and third parties should also be considered. The effect of the revocation of a lawful decision that is beneficial to a party shall be retroactive only if it occurs within a reasonable time.

The conception of the Model Rules underlines in Book III, that the possibility to revoke a decision calls for a balancing of the interest of the public with those of the beneficiary, considering the extent to which the illegality that besets the decision is obvious, whether the beneficiary had provoked the earlier decision through false or incomplete information and the extent to which the beneficiaries undertook irreversible investments because they relied on the decision (Hofmann, et al., 2014). 


\section{COMPARATIVE LAW METHODS FOR TERMINATION OF THE EFFECTS OF A SINGLE-CASE (INDIVIDUAL) ADMINISTRATIVE DECISION BY AN ADMINISTRATIVE AUTHORITY IN THE LAW OF SOME BALKAN COUNTRIES}

\subsection{Albania}

According to the Code of Administrative Procedures (CAP) adopted by Law No. $44 / 2015$, which entered into force in 2016, abrogation, annulment and revocation are regulated as ex officio remedies at the disposal of the issuing administrative authority, its hierarchicially superior authority or another authority explicitly mentioned by law. Only the effect of annulment is retroactive (ex tunc). The Code follows the ReNEUAL Model Rules, distinguishing remedies according to the conduct of the parties. If the beneficiary party is in good faith (not being aware of or negligent), the unlawful beneficial administrative act need not be annulled but only abrogated (Koprić, et al., 2016, pp. 112-113). The legal norms try to maintain a good balance between the principle of legal certainty and the principle of legality in the activity of public administration (SIGMA, 2018, pp. 267-273). The CAP does not mention time-limits for annulment or revocation.

\subsection{Bosnia and Herzegovina}

According to the Law on Administrative Procedure, published in the Official Gazette of Bosnia and Herzegovina, No. 29/02, administrative decisions may be revoked under the right of supervision. Under this right, according to Art. 252 para. 1, the competent authority shall revoke a decision which is final in the administrative procedure: (i) if the decision was issued by the actually competent authority and it is not the case provided in Article 256, point 1 of the law (was issued in the matter which falls within the judicial competence or in the matter on which a decision may not be taken in the administrative procedure at all); (ii) if a valid decision was previously issued in the same matter,by which that administrative matter was resolved differently; (iii) if the decision was issued by one authority without the consent, confirmation, permission or opinion of the other authority which is required by law or other provision based on the law; (iv) if the decision was taken as a result of compulsion, extortion, blackmail, pressures or any other illicit action. Also, according to the second para. of Art. 252, a decision which is final in the administrative procedure may be revoked with ex nunc effects under the right of supervision, if the substantive law has obviously been violated by it. In the matters in which two or more parties with opposing interests participate, the decision may be revoked only upon the consent of interested parties.

As for the time-limit, according to Art. 253, a decision on revocation, on the basis of point 1 and 2 of para. 1 and 2 of Article 252 of this law may be issued within the period of five years and on the basis of point 3, paragraph 1 of that Article - within the period of one year from the date when the decision became final in the administrative procedure. A decision on revocation of the decision, on the basis of Art. 252, para. 1, point 4 of this law, may be issued regardless of the periods laid down in para. 3 of this Article. 
Revocation with ex nunc effect of a valid decision is also possible with the party's consent or at the party's request. According to Art. 254, if the party acquired a right by a valid decision and the authority which issued it considers that the substantive law was incorrectly applied in it, it may revoke the decision for the purpose of its harmonisation with the law only if the party, which acquired that right on the basis of that decision, agrees to it and if the right of a third person is not violated by this. The party's consent is also required for an amendment to the valid decision that is detrimental for the party and that imposes a liability on the party.

Regarding the effect of the revocation based on Art. 254, it shall take effect only in the future.

According to Art. 255, an extraordinary revocation with ex nunc effect of executive decisions is possible if necessary for the purpose of eliminating a grave and imminent danger to the life and health of people, public security, public peace and order or public morality, or for the purpose of eliminating disruptions in the economy, if these could not be successfully eliminated by other means which would be less encroaching on the acquired rights. A decision may also be revoked only partially, to the extent sufficient to eliminate the danger or protect the mentioned public interest. The party who, due to the revocation of the decision, suffers damage shall have the right to claim only the compensation of the actual damage. The Court of Bosnia and Herzegovina shall be responsible to take a decision as per a request for compensation of damage.

\subsection{Croatia}

The general Administrative procedure Act published in the Official Gazette of Croatia no. 47/2009 contains dispositions regarding the annulment or repeal ${ }^{315}$ of unlawful or lawful administrative decisions.

Annulment is sanctioning of unlawful decisions. According to Art. 129, a decision under which a party was conferred a right may be annulled when (i) the decision is rendered by a public law authority without jurisdiction or when the decision is rendered without the consent, approval or opinion of another public law authority required by law, (ii) a legally effective decision is rendered in the same matter, whereunder the same administrative matter is resolved in some other way. In the event of an express violation of substantive law, a decision under which a party was conferred a right may be annulled or repealed, depending on the nature of the administrative matter and the consequences arising from the annulment or repeal.

Repeal may be applied for lawful administrative decisions under which a party was conferred a right in the following situations: (i) the repeal of this decision is permitted by law, (ii) it contains an exclusion of repeal and the party failed to meet its obligation from the decision or failed to meet it in due time, (iii) this is necessary in order to prevent serious and immediate danger to the life and health of people or public safety, and this could not be done by other means which would interfere less with the attained rights; when

315 The term "repeal" is used in the official translation of the normative act discussed. Considering the terms and effects described by the law, we can conclude that it is a case of revocation of a single-case administrative decisions. 
the decision is repealed for the purpose of preventing a serious and immediate danger to the life and health of people or public safety, the party is entitled to reimbursement of real damages (Art. 130).

A public law authority shall reach a decision on the annulment or repeal of a decision $e x$ officio, at the proposal of a party or an authorised state body. A decision may be annulled or repealed by the public law authority which rendered it; when the decision was rendered by a body of first instance it can be annulled or repealed by a body of second instance and when there is no body of second instance, the decision may be repealed by the body which pursuant to law supervises this body (Art. 131). According to Art. 129, an illegal decision may be annulled or repealed entirely or in part even after the expiry of the period of appeal and according to Art. 131 unlawful decisions may be annulled within two years and repealed within one year following the date of the decision's delivery to the party, in which cases the decision must be sent out from the body which reached it within this time limit.

\subsection{Greece}

The Administrative Procedure Code ratified by the Law no. 2690 was published in the Official Gazette of the Hellenic Republic, no. 45/1999. According to the dispositions of Art. 24 and art. 25, the issuing authority may revoke and the superior hierarchic authority or another competent authority may annul a single-case (individual) administrative decision at the request of the interested party, in order to provide the restitution of material or moral prejudice of lawful interests caused by an administrative decision. A general time-limit for an administrative appeal is not set in the Code for simple administrative appeals. Special administrative appeals may be lodged, when provided by special provisions, in which case the time-limit for such an action is the one provided by the law and has to be mentioned in the administrative decision. Generally, annulment may occur in respect of legality of the administrative decision, but the review of the administrative decision may extent to the merits of the case issues (Auby, 2014, pp. 241-242).

\subsection{North Macedonia}

The general Administrative Procedure act adopted in July 2015 and published in the Official Gazette of the former Yugoslav Republic of Macedonia no. 124/15, proclaims the principle of the validity of the administrative decision, which means the irrevocability of the decision by the public authority or permissibility to be annulled or amended only in cases determined by law. According to Pavlovska-Daneva \& Davitkovska (2017, p. 274 ) these rather drastic stability measures are prescribed primarily in order to protect the beneficiary from revocation of the decision by the public authority that issued it and to prevent the party from initiating a retrial on the same subject. It is considered that this principle contains the protection of the acquired rights of the party. The theory differentiates between material and formal validity. The first refers to a ban on the public authority revoking the act, and formal validity is an obstacle for the parties to challenge the act using legal remedies. 


\subsection{Slovenia}

According to the General Administrative Procedure Act published in the Official Gazette of the Republic of Slovenia no. 24/2009, the effects of an administrative decision may be terminated as a result of an administrative appeal or ex officio (Art. 260-280). The power of the administration to "remedy" ex officio is considered an exceptional one, due to the principle of the stability of the "acquired rights". The annulment ab initio of a decision is part of the supervisory right (Art. 274). This is regarded as „a tool for the line ministries (or supervisory bodies superior to those issuing the decision) to ensure legality in a certain area" and the right exists even if the law does not explicitly define the competent authority (e.g. the supervisory right over an inter-ministerial commission is held by the Government and that over the information commissioner by the National Assembly) (Koprić, et al., 2016, p. 129). The procedure can be initiated both ex officio and at the request of the party. The state prosecutor, the state attorney, or an inspector may also ask for the initiation of the procedure. The decision can be annulled ab initio within five years, or within one year from issuing in cases of violation of jurisdiction (subject matter, territorial, collective decision) or interferences with substantive finality (a different decision is issued in the same matter). The supervisory body can also annul a decision in the event of evident violation of substantive regulation.

Extraordinary annulment is possible where the execution of a given right interferes with the public interest. Extraordinary annulment is carried out by the supervisory body. The party who thus lost its legally granted right has the right to compensation.

\subsection{Conclusions regarding the comparative study}

A brief consideration of the legislation of the Balkan countries aforementioned shows that there are rules for terminating the effects of single-case administrative decisions, but the rules regarding the competent administrative authorities, reasons, effects of revocation or annulment are different, as are the time limits to exercise this power and the obligations of the administrative bodies to compensate the damage caused by revocation. The balance usually considered is between the principle of stability of legal relations and the principle of legality of the activity of public administration. In order to keep the balance, different types of rules concerning the reasons for revoking a single-case administrative decision and the time limit to do so are combined. For strengthening the principle of stability of legal relations, in some legal systems the revocation is considered basically inadmissible (North Macedonia) or revocation with ex nunc effects is considered to be the remedy if the beneficiary of the revoked decision was in good faith (Albania) or only if the party, which on the basis of that decision acquired that right, agrees to it and if the right of a third person is not violated by this (Bosnia and Herzegovina). Situations that occur after the issuing of a single-case administrative decision, such as protecting the public interest or noncomplying with the obligations linked to the issuing of administrative act may be reasons for revoking single-case administrative decisions according to the law (Albania, Bosnia and Hertzegovina, Croatia, Slovenia). 


\section{GENERAL CONCLUSIONS}

Analysing the possibilities of the administrative bodies to terminate the effects of single-case (individual) administrative decision in the legislation of the Balkan countries aforementioned and Romania, we can say that there is an evident will of the countries to adopt legislation in accordance with democratic principles. The possibilities of the administration ex officio to terminate the effects of single-case (individual) administrative decisions differ significantly in the analysed legislations, from a right to do so in almost any situation (like the Romanian legislation) to an exceptional situation (the Slovenian legislation). Predictability and stability of legal relations are insured by providing a limited number of situations where the effects of unlawful or lawful decisions may be terminated by the administrative bodies. Such possibilities may be used ex officio or following an administrative appeal. The power of terminating the effects of an administrative decision belongs to the issuing authority or to another authority which has supervisory attributions upon the issuing body. Unlawful single-case (individual) administrative decisions are generally annulled. The termination of the effects of a single-case (individual) administrative decision may be a sanction, if the beneficiary of the decision failed to comply with the duties attached to the decision or failed to comply with them within the set time-limit. In most cases, the possibility to annul, or ex officio revoke a single-case (individual) administrative decision has a time-limit (years) in most cases, which, however, can exceed the time-limit for appealing the decision. A lawful single-case (individual) administrative decision may be revoked for reasons of public interest and the beneficiary is entitled to compensation in such cases.

Many of these rules are not to be found in the Romanian administrative procedure rules set out for the moment by the doctrine and case-law, such as the time limit for the ex officio revocation of a single-case (individual) administrative decision or the right to compensation in case of the revocation of a lawful decision. The Project for the Code of Administrative Procedure, on the other hand, provides stricter rules than the ones found in the surrounding Balkan area, such as the possibility of the administration to revoke single-case (individual) administrative decisions only on grounds related to legality and only withing the time-limit for appeal, even if the verification of the decision is done ex officio. Such rules, in our opinion are drifting away from the goal of aligning Romanian legislation to the European trend. However, mentioning clearly the situations when an administrative body may terminate the effects of single-case (individual) administrative decisions appears a much better solution that the one set in the ReNEUAL Model Rules where the possibility to withdraw an illegal decision should be analysed in connection with the extent to which a party has a legitimate expectation that the decision was lawful and the extent to which the party has relied on it, which may lead to insecurity in legal relations. Of course, there are many principles to balance, the general interest of maintaining only the effects of legal decisions and the stability of legal relations being only two of them. Legislation may be continuously improved in accordance with the manner the public administration respects the main rules for its conduct. 


\section{REFERENCES}

Anghene, M., 1958. Elemente de drept administrativ. Bucharest: Editura Ştiinţifică.

Anon., 2004. Proiectul Codului de procedură administrativă. Revista de drept public, Issue 4, pp. 25-54.

Auby, J.-B., ed., 2014. The Grrek Administrative Procedure Code. În: Codification of Administrative procedure. Bruxelles: Bruylant, pp. 236-244.

Drăganu, T., 1959. Actele de drept administrativ. Bucharest: Editura știinţifică.

Fodor, E.-M., 2016. About three administrative procedure rules from a human rights perspective. Law Review, 20 December, 6(Special Issue), pp. 218-238. http://www. internationallawreview.eu/fisiere/pdf/Law-review_nunar_special_2017_PAGINAT_ Fodor.pdf, 12.6.2020.

Fodor, E.-M., 2017. Drept administrativ. Cluj-Napoca: Albastra.

Foillard, P., 2009. Droit administratif. Orléans: Éditions Paradigme.

Ghimpu, S., 1985. Dreptul muncii. Bucharest: Editura didactică şi pedagogică.

HCCJ, 2008. Decision no. 205 from 22nd January 2008. In: Jurisprudenţa Secţiei de contencios administrativ şi fiscal pe anul 2008, semestrul I. Bucharest: Hamangiu.

Hofmann, H., Schneider, J.-P. \& Ziller, J., ed., 2014. The ReNEUAL Model Rules. www. reneual.eu, 1.9.2020.

Ionescu, R., 1970. Drept administrativ. Bucharest: Editura Didactică şi Pedagogică.

Iorgovan, A., 2001. Tratat de drept administrativ. Bucharest: All Beck.

Iovănaș, I., 1997. Drept administrativ. Arad: Servo-Sat.

Koprić, I., Kovač, P., Đulabić, V. \& Džinić, J., 2016. Legal Remedies in Administrative Procedures in Western Balkans, s.l.: Regional School of Public Administration (ReSPA), https://www.respaweb.eu/11/library, 19.7.2020.

Pavlovska-Daneva, A. \& Davitkovska, E., 2017. The Macedonian General Administrative Procedure Act: Between Tradition and Modernisation. Croatian and comparative public administration, 17(2), pp. 263-290, https://hrcak.srce.hr/183530, 18.7.2020.

Petrescu, R.-N., 1997. Drept administrativ. 2 ed. Cluj-Napoca: Cordial Lex.

Petrescu, R.-N., 2004. Drept administrativ. Cluj-Napoca: Accent.

Popescu, C.-L., 2000. Protecţia internaţională a drepturilor omului - surse, instituţii, proceduri. Bucharest: All Beck.

Rivero, J. \& Waline, J., 2004. Droit administratif. 20th ed. Paris: Dalloz.

Santai, I., 2011. Drept administrativ și știinţa administraţiei. Sibiu: Alma Mater. 
SIGMA, Legal comentary by SIGMA on the Code of Administrative Procedure of the Republic of Albania, 2018. http://www.sigmaweb.org/publications/Legal-Commentary-bySIGMA-on-the-Code-of-Administrative-Procedures-of-the-Republic-of-AlbaniaApril-2018-edition.pdf, 13.10.2020. 